\title{
The revolution in online learning and implication in Vietnamese universities
}

\author{
Pham Thi Thu Huong ${ }^{1 *}$, Tran Thi Ngoc Giau ${ }^{1}$ \\ ${ }^{1}$ An Giang University, Vietnam \\ *Corresponding author: ptthuong@agu.edu.vn
}

\begin{abstract}
ARTICLE INFO
ABSTRACT

DOI: $10.46223 /$ HCMCOUJS.

soci.en.9.1.272.2019

Received: April $9^{\text {th }}, 2019$

Revised: July $6^{\text {th }}, 2019$

Accepted: July $17^{\text {th }}, 2019$

Keywords:

online learning in Vietnam, online learning, quality assessment in online learning, traditional learning

Online education has rapidly become popular worldwide in higher education. There are massive open online courses which could be found in Coursera and EDX. These courses ensure the availability and accessibility of online learning through videos with subtitles. Online learning not only gives students unprecedented opportunities to learn but also reduces the cost of higher education. However, online learning presents unit challenges compared to traditional learning, especially in Vietnamese education. In this paper, we present the advantages and disadvantages of online learning. In particular, we will show the advantages and disadvantages of taking online courses for Vietnamese students. We will also share our experience as a tutor at Funix University which is the first online university in Vietnam. In addition, we will give feasible suggestions to improve the quality of online learning in Vietnamese universities, especially the quality of assessment in online learning. These suggestions could be applied in building new online courses in the universities.
\end{abstract}

\section{Introduction}

MOOCs, which stands for massive open online courses, have suddenly become one of the hottest trends in high education such as Coursera and edX. MOOCs are free online university courses offered by colleges all over the world. Quality courses are available in a huge variety of subjects (Elliott, 2017; Kaplan \& Haenlein, 2016; Mazoue, 2013).

MOOCs are a great way to access quality education inexpensively and easily. Many of the top universities have now set up free or low-cost online versions of their courses. The courses are called "massive" because there's no limit on enrollment. MOOCs have incredibly large numbers of students. Anyone around the world can register and students don't need any special qualifications to register for a topic on MOOCs.

Online learning can fit into your own schedule and works best for students (Kaplan \& Haenlein, 2016; Kentor, 2015; Shah, 2019; M. Zhu, Curt, \& Annisa, 2019). When students sign up for a course, they can access the course materials online, usually in the form of recorded video 
lectures and written class notes. Most of the course is delivered in the form of videos, but students can also read extra materials online, collaborate with other students on projects, and participate in class forums. After registering, students will typically work at their own pace to watch informative lectures and lessons, complete assignments and exams. There are weekly quizzes and assignments. The quizzes are graded automatically. To gain a certificate of completion, learners just need to show that they have completed most of the quizzes, assignments and exams. While they won't receive university credit, they will get a certificate for completing all the coursework.

Although online learning has many advantages that would bring benefits for students, there are some strong concerns about the role of the teacher, learner participation and assessment (Admiraal, Huisman, \& Pilli, 2015; Kentor, 2015). In MOOCs, there is a lack of interaction between teachers and students. Because of the numbers involved, there's not much chance to interact directly with the teacher, although students can connect with other fellow students to ask questions or collaborate on assignments. In addition, it is difficult to keep track of students' involvement. Dropout rates are typically high. Finally, the assessment of this type of learning has a major challenge. With the large numbers of participants and complex topics, online learning gives less accurate assessments of the writing assignments.

About open education - MOOC in Vietnam, Giap school online education (https://giapschool.com/) by Dr. Giap Van Duong and colleagues (August 2013) is an open, complete online course (Do, 2017; Le, 2018). It's a free program in Vietnam. After nearly 5 years of operation, Giap school has been well known. Currently, on the website, there are more than 11,687 students participated in 24 courses. FPT University has been applied using MOOC since May 2015 and see here is a top priority in the training program create this school in the future. University of natural sciences Ho Chi Minh City has started testing the integrated program lectures on Khan Academy in 2018. This program has offered basic math and science subjects for free from grade 1 to university level.

Online learning in high education has been introduced to Vietnam recently. There are just a few of full online Universities in Vietnam (Do, 2017; Le, 2018). Funix University, which is the first online university in Vietnam, officially opened in November 2015. Teaching and learning activities are organized and managed with a new method called FUNiX Way. Quality online resources are taken from prestigious universities in the world, especially from edX and Coursera. Funix Univesity has collaborated with other universities and educational institutes in Vietnam and all around the world. The university has also built a strong mentor group, including professional and leading experts. Another online university in Vietnam is Topica University which opened for high education in March 2016. Topica Edtech Group is a leading online education provider in South East Asia. This group has partnered with 16 universities across Philippines, Vietnam and the United States.

This paper is divided into 4 sections. The second section presents the advantages and disadvantages of online learning in Vietnam universities. Section 3 deals with some suggestions to improve the quality of online learning in Vietnamese universities. Finally, Section 4 includes a discussion and future research about this area.

\section{Advantages and disadvantages of online learning in Vietnamese universities}

In this section, we would like to present the advantages and disadvantages of online learning in Vietnamese universities (Table 1). In order to emphasize the pros and cons of online learning in Vietnam, we will present the features of traditional learning, international online 
learning and Vietnamese online learning about learning environment, resources, studying skills and assessment. Based on these features, the pros and cons of the three types of learning will be compared. We can see that the advantages of traditional learning could be the drawbacks of online learning and vice versa. For the young and new type of learning in Vietnamese education, learning online will add more difficulties compared to international learning online.

About learning environment, online learning can create flexible ways for students to choose time and place for studying (Elliott, 2017; Kaplan \& Haenlein, 2016; Shah, 2019; M. Zhu et al., 2019). Students can choose where to study and when to study which suit their schedules the best. This feature is one of the prominent features which are different from traditional learning. Another advantage of online learning is that a big group of effective and friendly mentors and supportive online services will be available to help students with their studies.

However, this flexible learning environment of learning online, it can also cause some possible disadvantages (Admiraal et al., 2015; Mazoue, 2013; Xiong \& Suen, 2018; A. Zhu, 2012), especially in the educational environment of Vietnam. It is hard to monitor and manage the studying time and studying the progress of students. This requires that students need to have strong motivation and time management of their own study. And students also need to have the ability to seek help and search for information when they struggle with understanding difficult knowledge. Another difficulty that cannot be ignored is about hiring and building a group of effective and enthusiastic mentors. Most of the mentors work for online universities as part time job. They are already full-time lecturers or experts in other universities or companies. So, hiring these experts and lecturers and using their spare time or outside working hours are difficult and costly. Moreover, choosing online meeting time between mentors and each student for raising questions and giving advice is not an easy job. For example, in the Funix university, the advising time is from $8 \mathrm{pm}$ to $11 \mathrm{pm}$ for weekdays and adding 4 hours from 9 am to 11 am and from 15 $\mathrm{pm}$ to $17 \mathrm{pm}$ on Sunday. It is definitely very costly to have an expert outside working time and also take a lot of effort from mentor to explain and guide each of the student's questions from different backgrounds and issues.

\section{Table 1}

Advantages and disadvantages of traditional learning, international online learning and online learning in Vietnam

\begin{tabular}{|l|l|l|l|}
\hline & \multicolumn{1}{|c|}{ Traditional learning } & \multicolumn{1}{|c|}{$\begin{array}{c}\text { International online } \\
\text { learning }\end{array}$} & $\begin{array}{l}\text { Online learning in } \\
\text { Vietnam }\end{array}$ \\
\hline $\begin{array}{l}\text { Learning } \\
\text { environment } \\
\text { (place, teacher, } \\
\text { communication) }\end{array}$ & $\begin{array}{l}\text { - Place: lecture rooms } \\
\text { - Teacher: lecturer, } \\
\text { librarians, tutors } \\
\text { - Communication: face } \\
\text { to face discussion }\end{array}$ & $\begin{array}{l}\text { - Place: at home } \\
\text { - Teacher: mentors } \\
\text { - Communication: email, } \\
\text { voicemail, text message, } \\
\text { video conference, chat } \\
\text { room, discussion board }\end{array}$ & $\begin{array}{l}\text { - Place: at home } \\
\text { - Teacher: mentors } \\
\text { - Communication: } \\
\text { email, voicemail, } \\
\text { text message, video } \\
\text { conference and chat } \\
\text { room }\end{array}$ \\
\hline Advantages & $\begin{array}{l}\text { - Having traditional } \\
\text { environment for } \\
\text { studying and } \\
\text { monitoring and }\end{array}$ & $\begin{array}{l}\text { - Flexible places and time for studying } \\
\text { - Supportive discussion forums with an effective } \\
\text { group of mentors }\end{array}$ \\
\hline
\end{tabular}




\begin{tabular}{|c|c|c|c|}
\hline & Traditional learning & $\begin{array}{c}\text { International online } \\
\text { learning }\end{array}$ & $\begin{array}{c}\text { Online learning in } \\
\text { Vietnam }\end{array}$ \\
\hline & $\begin{array}{l}\text { encouraging students } \\
\text { for their study } \\
\text { - Having face to face } \\
\text { discussion and } \\
\text { communication }\end{array}$ & & \\
\hline $\begin{array}{l}\text { Possible } \\
\text { disadvantages }\end{array}$ & $\begin{array}{l}\text { Do not have the } \\
\text { flexibility to serve } \\
\text { students' need }\end{array}$ & $\begin{array}{l}\text { - Need to have a strong } \\
\text { supportive online service to } \\
\text { monitor and motivate } \\
\text { students' study process } \\
\text { - Lack of face to face } \\
\text { communication }\end{array}$ & $\begin{array}{l}\text { Adding difficulties } \\
\text { - Difficult to hire } \\
\text { qualified mentor and } \\
\text { fix time between } \\
\text { mentor and student }\end{array}$ \\
\hline Resources & - Lecture notes, books & - Ebooks, video lectures & $\begin{array}{l}\text { - Ebooks, video } \\
\text { lectures }\end{array}$ \\
\hline Advantages & $\begin{array}{l}\text { The knowledge Suit } \\
\text { with students' level }\end{array}$ & \multicolumn{2}{|c|}{$\begin{array}{l}\text { - Huge number of qualified sources and materials } \\
\text { on the internet } \\
\text { - The teaching materials from prestigious } \\
\text { universities in the world }\end{array}$} \\
\hline $\begin{array}{l}\text { Possible } \\
\text { disadvantages }\end{array}$ & $\begin{array}{l}\text { More focused and } \\
\text { limited in the materials } \\
\text { that teacher introduce } \\
\text { students }\end{array}$ & $\begin{array}{l}\text { - Students need to have } \\
\text { searching and analyzing } \\
\text { skills } \\
\text { - Students need to have a } \\
\text { very strong motivation and } \\
\text { self-study ability } \\
\text { - Need quick and effective } \\
\text { supports and guides from } \\
\text { staff and mentors for each } \\
\text { student }\end{array}$ & $\begin{array}{l}\text { Adding difficulties } \\
\text { - Most of material } \\
\text { has in English } \\
\text { language. } \\
\text { - It is difficult to } \\
\text { orient and motivates } \\
\text { students for doing } \\
\text { research on a subject }\end{array}$ \\
\hline Studying skills & $\begin{array}{l}\text { - Instruction and } \\
\text { strategies provided by } \\
\text { the lecturer } \\
\text { - Lecturer plans the } \\
\text { syllabus and timetable } \\
\text { for each week }\end{array}$ & $\begin{array}{l}\text { - Study guide and strategies } \\
\text { website } \\
\text { - Students plan and manage } \\
\text { their own learning time }\end{array}$ & $\begin{array}{l}\text { - Study guide and } \\
\text { strategies website } \\
\text { - Students plan and } \\
\text { manage their own } \\
\text { learning time }\end{array}$ \\
\hline Advantages & $\begin{array}{l}\text { There are many } \\
\text { activities such as group } \\
\text { work, discussion } \\
\text { happened in classrooms }\end{array}$ & \multicolumn{2}{|c|}{$\begin{array}{l}\text { - Allow each student to study at his or her own pace } \\
\text { - Focus on the individual learners' differences } \\
\text { - Having a large connection between learners } \\
\text { coming from different places and courses. }\end{array}$} \\
\hline $\begin{array}{l}\text { Possible } \\
\text { disadvantages }\end{array}$ & $\begin{array}{l}\text { May not suit and fit for } \\
\text { each student on a class }\end{array}$ & $\begin{array}{l}\text { May impact socialization } \\
\text { skills }\end{array}$ & $\begin{array}{l}\text { Adding difficulties } \\
\text { - May limit the role } \\
\text { of instructors or } \\
\text { mentors }\end{array}$ \\
\hline $\begin{array}{l}\text { Assessment } \\
\text { (Assignments and } \\
\text { exams and } \\
\text { evaluation) }\end{array}$ & $\begin{array}{l}\text {-Traditional proctored } \\
\text { exams } \\
\text { - Self and peer } \\
\text { assessments, provide } \\
\text { feedback to the entire } \\
\text { class }\end{array}$ & $\begin{array}{l}\text { - Written assignments and } \\
\text { online discussion via video } \\
\text { conference } \\
\text { - self-check assessment }\end{array}$ & $\begin{array}{l}\text { - Written } \\
\text { assignments and } \\
\text { online discussion } \\
\text { - self-check } \\
\text { assessment }\end{array}$ \\
\hline
\end{tabular}




\begin{tabular}{|l|l|l|l|}
\hline & \multicolumn{1}{|c|}{ Traditional learning } & \multicolumn{1}{|c|}{$\begin{array}{c}\text { International online } \\
\text { learning }\end{array}$} & $\begin{array}{c}\text { Online learning in } \\
\text { Vietnam }\end{array}$ \\
\hline Advantages & $\begin{array}{l}\text { - Many types of exam } \\
\text { can be organized } \\
\text { - Be able to control the } \\
\text { quality and the fairness } \\
\text { of exams }\end{array}$ & $\begin{array}{l}\text { - Having fewer advantages than traditional learning } \\
\text { on assessment }\end{array}$ \\
\hline $\begin{array}{l}\text { Possible } \\
\text { disadvantages }\end{array}$ & Inapplicable & $\begin{array}{l}\text { - Do not have many types } \\
\text { of exams } \\
\text { - May take more effort to } \\
\text { assess students' work }\end{array}$ & $\begin{array}{l}\text { Adding difficulties } \\
\text { - May not control the } \\
\text { quality and the } \\
\text { fairness of exams }\end{array}$ \\
\hline
\end{tabular}

Source: The researcher's data analysis

The next feature we would like to discuss is resources in online learning (Kaplan \& Haenlein, 2016; Mazoue, 2013; Shah, 2019; M. Zhu et al., 2019). There are a huge number of qualified sources and teaching materials on the internet for students to study. Moreover, online universities have a connection with famous universities and lectures. Therefore, they can provide many qualified video lectures, lecture notes from prestigious and well-known lecturers. However, these also can cause some disadvantages in Vietnamese online university. Students need to have searching and analyzing skills because so many materials are available and introduced. It will take time and effort to study and analyze all of them. To do this, students need to have a very strong motivation and self-study ability. Moreover, to support students immediately when they need help, online universities need to have effective and supportive online services and a group of available mentors. In addition, most of qualified online teaching materials and video lectures are used in online universities are in English language. So, it is probably difficult to orient and motivate students on their study and doing research, especially for Vietnamese students.

Online learning encourages self-study from students (Elliott, 2017; Kaplan \& Haenlein, 2016; Xiong \& Suen, 2018; A. Zhu, 2012). It attracts students who have the same interest in the courses through flexible and valuable programs. So, it requires students to be more independent in online learning than in traditional learning. This type of learning allows each student to study at his or her own pace. In online learning, the starting of each subject or course of each student is different and the length of course for each student also depends on students' choice. Students can learn slow or fast, focus on a certain part of the course or review the entire course. These ways of learning increase satisfaction and release stress. However, not all students know the studying skills in the university and have independence in learning. With an online relationship and online communication, students may not feel comfortable to discuss and raise questions. In addition, though students might have excellent academic knowledge, they may not possess the necessary skills to deliver their acquired knowledge to others. The role of mentor in online learning is different from the role of lecturer in traditional school. They just answer the questions and guide students to obtain certain knowledge. They do not know the process of study for a specific subject or for the whole studying process of students.

About assessment, online learning has faced more difficulties than traditional learning. Online learning may also be subject to piracy, plagiarism, cheating, inadequate selection skills, and inappropriate use of copy and paste. Traditional proctored exams and face to face interview exams cannot be organized in online learning instead of written assignments and online 
discussions. In Vietnamese environment, it is hard to control the fairness and cheating by just looking at and marking students' assignments. To reduce this impact, in Funix university, besides one writing assignment, they organized the online interview final exams. These final exams last for 20 minutes. In these exams, there are two mentors will ask students about general knowledge of the subject and about the assignment to make sure that it is solved by her or him.

\section{Suggestions to improve the quality of online learning in Vietnamese universities}

Based on the disadvantages of online learning in Vietnamese universities listed in Section 2, some suggestions are provided to improve the quality of online learning in Vietnamese universities. We focus on improving resources, the quality of mentors and the way of assessment.

First, there are three main things Vietnamese universities should accomplish to build widen and available resources. The learning online system should be built in each university. This system is a learning and teaching platform which facilitates the creation of online educational environments. This system can be used to create entire online topics and courses, or to provide interactive tools that supplement or complement existing topics and courses. In addition, if Vietnamese universities take video lessons from international online universities such as EDX or Coursera, the Vietnamese subtitles for these video lessons must be provided. Students will have the choice to listen to English lessons or check for Vietnamese subtitles in case of confusion. Finally, we should build our own video or audio lessons, lecture notes, assignments, interactive exercises, tutorial activities and exams that suit our purpose of teaching and the level of our students. In order to do this, online learning support services need to be established along with the learning online system. This service will support academic and professional staff to use the learning online system. This service will also assist with the effective use of tools and activities in the online environment such as designing templates, sites, transferring materials and making effective video lessons.

Second, in order to establish a good mentor team, universities should focus on promoting discussion forums, building good mentors from lectures of their own university and attracting professional and experienced mentors from other universities and famous companies. We should build and encourage students to join in discussion forums. Universities not only count on students' questions for mentors as Funix University way but also students' questions and answers from the discussion forum. From this activity, students will gain more knowledge from their peers than just asking mentors. Universities should also train their own lecturers to become good mentors. These mentors will be the main online staff who provide knowledge, guidance and constructive answers. Finally, universities should invite professional and experienced mentors who will share skills, expertise and act as positive role models. These mentors could be famous lectures from other universities or leaders in successful companies who exhibit enthusiasm and value ongoing learning and growth in their field.

Finally, the quality of education depends essentially on the quality of assessment. Because we do not have an effective plagiarism detection service in Vietnamese language, we should focus on plagiarism detection in students' work, especially the final exam of courses. Although international online courses send online assignments and exams, in Vietnamese educational environment, universities should not do this. We should make sure that students do 
exams by themselves through interview exams or traditional exams on campus. The interview exams could be face to face setting on the campus or via recorded skype interview. Universities also should expand ways to testing such as peer assessments, quizzes and assignments. The important thing is that universities should cooperate with each other to build trusted Vietnamese plagiarism detection services. This will help students learn to avoid plagiarism and improve their writing and also help mentors with assessments.

\section{Conclusion}

Online learning has become popular in high education worldwide. This trend has gradually developed in Vietnam with many advantages compared to traditional education. Vietnamese universities should notice this development to keep up with the new online education. In order to provide the best quality, flexible and available courses for students, the universities should build their own learning online system. They could arrange blended learning which combined traditional learning and online learning. They could also cooperate with other online universities to build courses which represent the prestige of their university. In order to improve the quality of online education, the universities should focus on promoting resources, quality mentors and the way of assessment.

\section{References}

Admiraal, W., Huisman, B., \& Pilli, O. (2015). Assessment in massive open online courses. Electronic Journal of E-learning, 13(4), 207-216.

Do, H. V. (2017). Tài nguyên giáo dục mở - yếu tố tích cực cho đổi mới giáo dục đại học và mục tiêu phát triển bền vững quốc gia [Open education resources - positive factors for higher education innovation and national sustainable development goals]. Tap chí Thông tin và Tu liệu, 5, 3-14.

Elliott, J. C. (2017). The evolution from traditional to online professional development: A review. Journal of Digital Learning in Teacher Education, 33(3), 114-125.

Kaplan, A. M., \& Haenlein, M. (2016). Higher education and the digital revolution: About MOOCs, SPOCs, social media, and the cookie monster. Business Horizons, 59(4), 44150. doi:10.1016/j.bushor.2016.03.008

Kentor, H. (2015). Distance education and the evolution of online learning in the United States. Curriculum and Teaching Dialogue, 17, 21-34.

Le, D. N. (2018). Thư viện số, tài nguyên giáo dục mở góp phần thúc đẩy giáo dục mở Việt Nam [Digital libraries, open educational resources contribute to promoting open education in Vietnam]. Tạp chí Thông tin và Tu liệu, 2, 24.

Mazoue, J. G. (2013). The MOOC model: Challenging traditional education. Retrieved March 21, 2018, from Educause review website: https://er.educause.edu/articles/2013/1/themooc-model-challenging-traditional-education

Shah, D. (2019). Year of MOOC-based degrees: A review of MOOC stats and trends in 2018. Retrieved March 22, 2018, from https://www.classcentral.com/moocs-year-in-review2018 
Xiong, Y., \& Suen, H. K. (2018). Assessment approaches in massive open online courses: Possibilities, challenges and future directions. International Review of Education, 64(2), 241-263.

Zhu, A. (2012). Massive open online courses - A threat or opportunity to universities. Retrieved March 23, 2018, from http://www.forbes.com/sites/sap/2012/09/06/massive-openonline-course-a-threat-or-opportunity-to-universi-ties.

Zhu, M., Curt, B., \& Annisa, S. (2019). Massive open online course instructor motivations, innovations, and designs: Surveys, interviews, and course reviews. Canadian Journal of Learning and Technology, 45(1), 1-20. 